
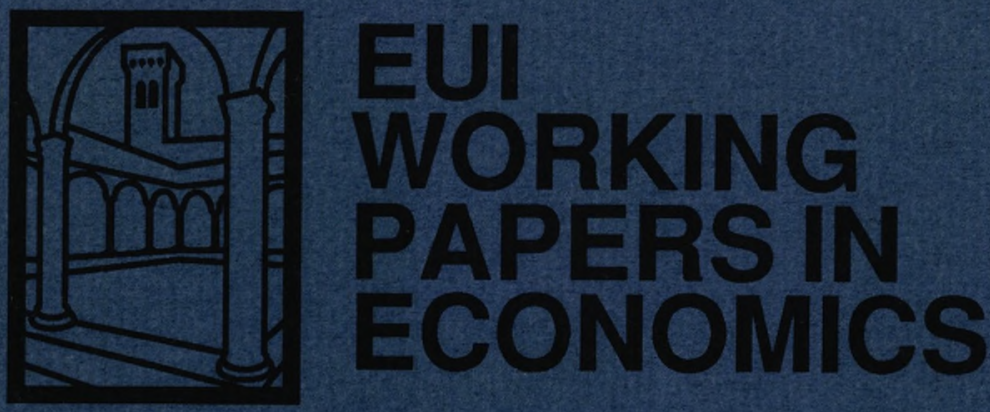

EUI Working Paper ECO No. $91 / 56$

Why do Women Married to Unemployed Men have Low Participation Rates?

JOHN MICKLEWRIGHT and

Gianna Giannelu 
European University Library

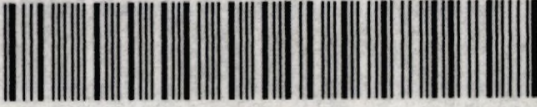

30001001354648

Please note

As from January 1990 the EUI Working Paper Series is divided into six sub-series, each sub-series is numbered individually (e.g. EUI Working Paper LA W No. 90/1). 


\section{EUROPEAN UNIVERSITY INSTITUTE, FLORENCE ECONOMICS DEPARTMENT}

EUI Working Paper ECO No. 91/56

Why do Women Married to Unemployed Men have Low Participation Rates?

JOHN MICKLEWRIGHT

and

GIANNA GIANNELLI

BADIA FIESOLANA, SAN DOMENICO (FI) 
All rights reserved.

No part of this paper may be reproduced in any form without permission of the authors.

(C) John Micklewright and Gianna Giannelli Printed in Italy in November 1991

European University Institute

Badia Fiesolana

I-50016 San Domenico (FI)

Italy 


\title{
WHY DO WOMEN MARRIED TO UNEMPLOYED MEN HAVE LOW PARTICIPATION RATES?
}

\author{
Evidence from Panel Data
}

John Mick lewright* and Gianna Gianne $11 i^{* *}$

November 1991

\begin{abstract}
European University Institute, Florence, and
Queen Mary and Westfield College, University of London

* European University Institute, Florence.
\end{abstract}

\begin{abstract}
In a number of countries, women married to unemployed men have lower participation rates in paid work than do wives of employed men - the reverse situation of that suggested by the added worker effect. One possibility is that the employment status of the husband proxies characteristics of the wife associated with a low probability of her being employed. Another is that the labour supply of the wife may be affected by the type of unemployment benefit received by her husband, a disincentive effect arising when this benefit is means-tested on family income. We investigate these issues using panel data on married women in Germany covering five years. The panel nature of the data is used to control for unobservable fixed-effects which may be correlated with the husband's employment status and type of benefit if unemployed. We est imate the Chamberlain fixed-effect logit model using a two-stage technique for a panel with 60 periods. This technique avoids the excessive computational burden that arises with the use of a single stage conditional maximum likelihood approach when panels have more than a few periods.
\end{abstract}

\section{Acknowledgements}

We thank Christian Dustmann and Eckhard Wurzel for help in clarifying details of the German unemployment benefit scheme, Usch $i$ Jaenichen for advice on the SEP data, and Peter Blossfeld for providing access to these data through his research project at EUI. Thanks also to Wiji Narendranathan for correspondence on the conditional logit model. Stephen Jenkins made useful comments on an earlier version of the paper as did seminar participants in Bergamo, Brescia, Padova, Pisa, and IFS, London. We are particularly grateful to Costas Meghir for his suggestions. 


\section{Introduction}

What effect should the unemployment of one member of a family have on the labour supply of other members? The textbook discussion emphasises the possibility of an "added-worker" impact, this increasing the labour supply of other family members through an income effect. On this basis we would expect women married to unemployed men to have a higher labour force participation rate than women married to men who are employed. In fact, in a variety of countries the opposite is the case; women married to unemployed men often have lower participation rates. Table 1 shows the position for 11 countries; the participation rate in employment for the wives of unemployed men is significantly lower than for wives of working men at the one percent level on a chi-square test in 7 of the 11 countries and at the five percent level in one other. In no country is a significant pattern of the opposite kind found. In a number of countries the participation rate where the husband is unemployed is dramatically lower, and only in the USA (among those countries where the difference is significant) is the difference less than ten percent points.

Table 1

Labour Force Participation Rates of Women aged 20-54 Married to Household Heads

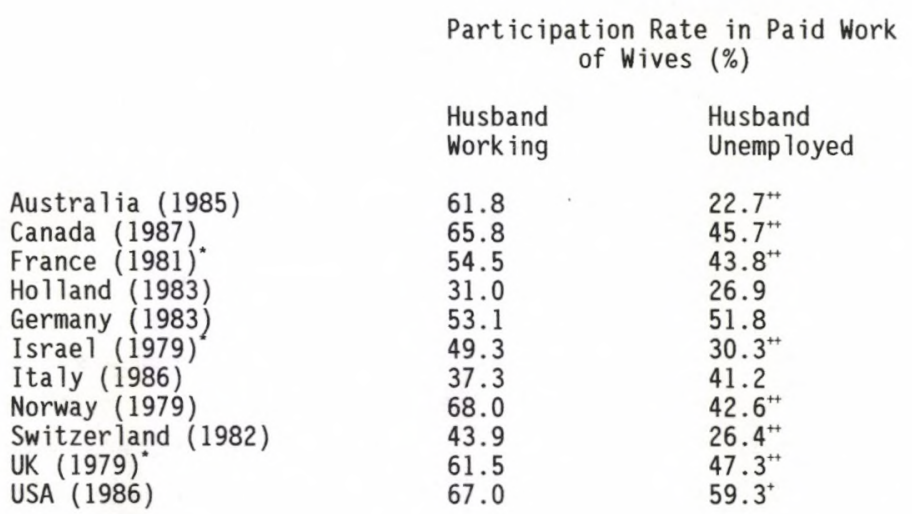

Notes: 1) "indicates that 'unemployed' includes a 11 husbands not working. 2) ${ }^{+}$and ${ }^{+}$indicate that the chi-square test statistic derived from a $2 \times 2$ table for each country is significant at the 1 and 5 percent level respectively.

Source: Luxembourg Income Study microdata (this source is described in Smeeding et a 1, 1990). 
of course, there are a number of possible reasons for the pattern in Table 1 which are consistent with the separate operation of an added worker effect. In particular, low participation rates may be the result of characteristics which are more common among the wives of the unemployed than among the wives of employed men such as low productivity and residence in areas of low labour demand. ${ }^{1}$ An issue with which we are particularly concerned in this paper is whether the employment status of the wife is affected by the type of unemployment benefit received by her husband (something that is not typically allowed for in the textbook discussion of unemployment and family labour supply). A disincentive effect for married women may be expected if unemployment benefits paid to their husbands are means-tested on family income, i.e. if benefits payable to an unemployed man are reduced when his wife has earned income. If this effect is important in practice then the policy choice between different types of unemployment benefits needs to make allowance for the labour supply effects on the whole family. This may put benefits which are not means-tested in a good light, such as the typical unemployment insurance benef it (Atk inson and Mick lewright, forthcoming).

The possible disincentives to family labour supply that may stem from the unemployment benefit system have been paid relatively little attention. An exception occurs in the UK (e.g. Garcia 1989 and 1991, Dilnot and Ke11 1989, Kel1 and Wright 1990) where the most important unemployment benefit (in terms of numbers of recipients at any one time) is means-tested on family income; the earnings of secondary earners are subject to an implicit 100 percent marginal rate of tax over a substantial range of hours. It is tempting to point to other countries in Table 1 and speculate as to whether the figures in the table reflect their benefit systems. For example, all unemployment benefit is subject to a family means-test in Australia; in the other countries in the table there is a "first-line" of income support provided by unemployment insurance, more or less free of a family means-test in every case. And Australia has both the lowest participation rate for wives of unemployed men of any country in the table and the greatest difference in rates between these wives and wives of employed men. On the other hand, there

1

In addition spouses' leisure consumption may be complementary. Lundberg (1985) argues that within a life-cycle the added-worker effect should be important only in the presence of credit constraints provided that the unemployment spel1 is sufficiently short to generate smal1 wealth effects. 
are countries in Table 1 where the wives of unemployed men have a lower participation rate but relatively little unemployment benefit is means-tested e.g. Canada and the US.

Progress in explaining participation rates for the wives of unemployed men can only be made by examining microdata in more detail. In what follows we analyse microdata from Germany. We choose this country for two reasons. Firstly, Germany, like the UK, is a country in which part of the unemployment benefit system is means-tested on family income and the disincentive outlined above may be expected to operate for the wives of some unemployed men (a)though the difference between participation rates of women married to employed and to unemployed men is not nearly as great as in the UK - see Table 1). Secondly, there are available panel data recording the labour force status of married couples for a substantial period; we exploit the panel nature of the data by allowing for unobserved fixed-effects which might be correlated with the husband's employment and benefit status. This cannot be done with cross-section data; despite the use of numerous control variables determining the wife's employment probability the possibility of omitted variable bias on the coefficients relating to the husband's status would always be present. In this context it may be noted that all three studies from the UK referred to above used cross-section data (as does that of Maloney, 1991, notwithstanding the title of the paper). ${ }^{2}$

Section 2 describes the relevant institutional features of the unemployment benefit system in Germany and our data; we use a sample of some 2,000 German couples drawn from the Socio-Economic Panel (SEP) for whom we observe the labour force status of each partner for 60 consecutive months spanning 1983-7. In Section 3 we estimate a binary model of the probability that the wife is employed in a given month, treating her husband's employment status as (strictly) exogenous. We attempt to establish whether the lower participation rate of wives of the unemployed is significantly associated with the unemployment benefit system or whether it is due to other observable characteristics together with unobservable influences. To this end we estimate the Chamberlain fixed-effect logit model. We present a two-stage technique for this mode 1 which avoids the excessive computational burden that arises with the use of the conditional maximum likelihood approach when panels

2

While writing up this research our attention was drawn to the work of Davies et al (1989) which does use panel data (from the UK) but which treats unobservables in a different way from us. 
have more than a few periods. Section 4 contains results and Section 5 concludes.

\section{German Unemployment Benefits and Panel Data}

What influence might the institutional details of unemployment benefits received by the husband in Germany be expected to have on the labour supply of the wife? Income support for the German unemployed is provided by three programmes. Eligibility for Unemployment Insurance ("Arbeitslosengeld") depends on the past employment history of the claimant and receipt is unaffected by any labour earnings of other persons in the family. of limited duration, Unemployment Insurance (UI) pays $63 \%$ of previous net earnings.

Unemployment Assistance ("Arbeitslosenhilfe") is payable either on the expiry of UI or if no eligibility for UI exists (in the latter case there is a minimal employment history requirement). Unemployment Assistance (UA) is means-tested at a rate of $100 \%$ on family income although the first DM150 per week (in 1989) of any income of the spouse (plus an additional DM70 for each child) is disregarded for the purpose of the means-test. Above the disregard, the net contribution to family income of the wife's labour supply is zero until her earnings in excess of the disregard equal her husband's UA entitlement. UA is also related to past earnings, with a replacement rate of $56 \%$. If both husband and wife faced the average industrial hourly wage for the ir respective sexes, the $100 \%$ implicit marginal tax rate would have applied to the wife throughout the range 10-48 hours in 1989 if there were no children (assuming the husband had previously worked 40 hours per week and no other income present). ${ }^{3}$ This indicates that the disincentive from the UA means-test may bind for a wide range of hours (the precise range depending on wages and family characteristics including other income).

The third benefit is Social Assistance ("Sozialhilfe") which is a residual means-tested benefit administered and paid for by local authorities; all of the spouse's earnings would be included in the calculation. Unlike UA, Social Assistance (SA) can be received at the same time as UI if sufficient need can be demonstrated. It can also supplement UA. Such "top-up" payments are rare if UI is in receipt; in 1985 only $5 \%$ of the unemployed with SA were

3 The average female hourly industrial wage in 1989 was DM14.76 per hour and that for men DM 20.09 (Statistisches Jahrbuch 1990, p.504). The replacement rates for both UI and UA are slightly higher if there are children present. 
also receiving UI while another $24 \%$ had UA payments (Brinkmann, 1988, table 18).

In $1986,64 \%$ of the total inflow (men and women) into registered unemployment received UI and $12 \%$ UA only; in the unemployed stock, exactly the same proportion of men were receiving the two benefits: $36 \%$; in 1985 some $13 \%$ of the registered stock were in receipt of SA (Brinkmann, 1988, tables 2 and $5)$.

The data we use to shed more light on the participation of the wives of unemployed men are drawn from the first five annual waves of the German SocioEconomic Panel (SEP); the first wave took place in 1984, interviewing some 5,000 households. In each wave respondents are asked to indicate the ir labour force status in each month in the preceding calendar year. We select a sample of 2,021 women continuously married throughout the 60 months concerned (and with their husband present in the household), aged 20-57 at interview in the first wave. ${ }^{4}$ The overall participation rate of the married women in the sample changes very little during the five years but there are substantial changes in participation at the individual leve $1 ; 26 \%$ of the women started work at least once in the period, $25 \%$ ceased working at least once, and $34 \%$ did one or the other, i.e. changed employment status.

In addition to the 2,021 women continuously married who we include, there are 438 women present in all five waves who are married for only part of the period. These we exclude. It should be noted however that since male unemployment may have an impact on marriage itself (e.g. Jensen and Smith, 1990 ) there may be an indirect influence on female participation as a result; by excluding those persons not continuously married we are in effect conditioning on the stability of marriage. We may also note that although the sub-sample we use represents a balanced panel the exclusion of those not continuously married or who do not respond in all waves is not in fact required by our econometric model; this could equally accommodate an unbalanced panel as we explain below. (We also exclude 59 continuously married women whose husbands did not respond to the survey in one or more years.)

About one-third of persons (men and women) interviewed in the first wave of the panel are missing from at least one of waves 2-5. 
Table 2

\title{
Labour Force Status of Husbands and Wives in the SEP sample 1983-87
}

\author{
Participation Rate
}

of Wife (\%)

Employed (90.1) $\quad 48.6$

Husband

Unemployed (3.5) $\quad 41.9$

Other $(6.1) \quad 46.5$

Status Missing (0.3\%) $\quad 41.7$

Note: the figures in brackets refer to the percentage of the total 120,568 observed months in which the husbands have the employment status indicated. These months relate to 2,021 couples (we have dropped those months in which the wives' employment status was missing). Participation of the wife is defined as paid employment.

Table 2 shows the labour force status of husbands and wives in the total of more than 120,000 months observed in the sample (the unit of analys is in the table is the month). Husbands are unemployed in less than four percent of these months, although given the large sample (in dimension $\mathrm{N}$ by $\mathrm{T}$ ) this represents over 4,000 observations. When the husbands are unemployed their wives have a participation rate in paid work which is 6.7 percent points less than when the husbands are employed, a difference which given the sample size is not surprisingly significant at any conventional level on a chi-square test. ${ }^{5}$

In Table 3 we focus on the months in which the husbands were unemployed and look at how the wives' labour force status varies with the type of benefit received by the husband. In addition to the retrospective collection of twelve months of employment status data in each sweep of the panel, respondents who have been unemployed are also asked to indicate in which months they received UI and in which UA. Unfortunately, no question is asked

5 This pattern is not inconsistent with Table 1 where the hypothes is of identical participation rates for wives of employed and unemployed men could not be rejected for Germany; the sample in Table 2 is far larger, being based on 60 observations for each couple rather than a single observation as is the case in Table 1. This permits significant differences to be detected in Table 2. 
about Social Assistance. Table 3 shows UA in receipt in a third of the observed months in our data.

Table 3

Wife's Labour Force Status in Months when Husband is Unemployed by Husband's Unemployment Benef it Type

Husband receiving:

A11 Months

$(\%)$

51.9

32.1

16.0

100.0

)
Participation Rate of Wife (\%) $\begin{aligned} & \text { Unemp loyment Insurance (UI) } \\ & \text { [not means-tested] }\end{aligned}$
Unemp loyment Assistance (UA)
[means-tested]

Neither UI nor UA
41.3

27.8

71.0

Note: The percentages in the table are based on a sample of 4,270 months. See also notes to Table 2 .

Conditional on the husband being unemployed, there are marked differences in the wife's employment status associated with the type of benefit he receives. The lowest participation rate - less than $30 \%$ - occurs where the husband is receiving UA; the highest participation rate - over $70 \%$ - is where neither UI nor UA is in receipt. Further investigation showed that the proportion of those participating who reported themselves as being in ful1-time work was lowest where UA was in payment to the husband and highest where neither UI nor UA was being received. Superficially, this evidence might appear consistent with both an added-worker effect when no benefit is received, and a means-test disincentive if UA is in payment, especially to full-time work. The lack of information in the data on Social Assistance payments makes it difficult however to read much into the situation where neither UI nor UA are received. More fundamentally, there may of course be no causal relationship between the participation rate and UA; the receipt of this benefit could merely be proxying other factors. This can only be 
revealed by multivariate analysis, to which we now turn.

\section{Estimating the Participation Probability}

We model the probability that the wives in our sample participate in paid work under the assumption that the husband's employment and benefit statuses are strictly exogenous (this rules out the need to model jointly the employment status of husband and wife). Armed with this assumption, one way to proceed would be to estimate a two state - employment and other - discrete time duration model in which the husband's employment status and type of unemployment benefit entered as time-varying covariates. ${ }^{6}$ We adopt a different (and simpler) approach, estimating a panel data version of the familiar reduced form binary choice mode1.' This keeps us closest to the descriptive analysis used so far in the paper on which we wish to throw more light; for the same reason we adopt a static framework. ${ }^{8}$ Our aim is to show whether econometric analys is of panel data confirms descriptive analysis rather than to estimate a full behavioural model of the participation decision.

Let:

$$
Y_{i t}=X_{i t}{ }^{\prime} b+Z_{i}{ }^{\prime} d+a_{i}+u_{i t}
$$

where we observe

$$
\begin{aligned}
D_{i t} & =1 \text { if } Y_{i t}>0 \\
& =0 \text { otherwise }
\end{aligned}
$$

$6 \quad$ Lundberg (1985) considers the added worker effect using a three state duration model but imposes stationarity on the hazard.

We do not pursue the full-time/part-time distinction further in this paper because recorded information appears to be based on the respondents' own definitions of these states rather than on any firm criterion of hours of work. We thus avoid the problem of whether the hours decision is determined in a different way to the participation decision.

It is worth noting that provided we wish to estimate the parameters of time-varying characteristics, parameters relating to lagged vàlues of the wife's employment status could not in any case be estimated with the conditional logit approach we describe below (Narendranathan and Elias 1990). A structural model in which we attempted to model budget constraints in detail is, in our view, beyond the ability of the data source which collects detailed information on incomes at only one point in the year. 
and where $D_{i t}=1$ if individual $i$ is employed in period $t$ and zero otherwise. The vectors $X_{i t}$ and the $Z_{i}$ are observed and we allow for the existence of an unobserved individual specific time-invariant $a_{i}$ as well as an IID error term $u_{i t}$. Our data provides $t=1.60$ observations on each $i=$ $1 . .1,885$ individuals. ${ }^{9}$

Our interest is in estimating the parameters b, i.e. coefficients of time-varying characteristics $\mathbf{X}_{i t}$ such as the husband's employment status and his type of unemployment benefit. In doing so we wish to allow for the possibility that the unobserved $a_{i}$ are correlated with the $x_{i t}$; this is our reason for using panel data. Is the low participation rate of wives whose husbands receive UA a result of this type of benefit proxying other characteristics which lower participation rates and which we do not observe and thus cannot condition on in $X_{i t}$ and $Z_{i}$ ?

To estimate the $\mathbf{b}$ in the presence of possibly correlated fixed-effects an appropriate technique (which places only mild restrictions on the $a_{i}$ ) is the conditional likelihood approach suggested by Chamberlain (1980) in which a logistic functional form for $p\left(D_{i t}=1\right)$ is assumed. As with any fixed-effect mode 1 , the coefficients of observed time-invariant characteristics, $\mathbf{d}_{i}$, cannot be estimated with this approach. This is not a worry since these characteristics are of no real interest to us. But a very real problem for the present exercise does exist with the Chamberlain model.

The computational burden for the conditional logit likelihood function rises sharply with T, the length of the panel (see e.g. Maddala 1987 pp316-7). A sufficient statistic for the unobserved $a_{i}$ is the sum of $D_{i t}$ over the length of the pane 1; conditioning on this sum the $a_{i}$ drops out of the expression for the conditional probability of the observed sequence of $D_{i t}$ for individual $i$ (as do the observed fixed characteristics, $\mathbf{d}_{i}$ ). There are T-1 possible sums which need to be considered. With $T=3$ the observed sequence of $D_{i t}$ over the panel for any individual will take one of any six possible forms, and with $T=4$ there are fourteen forms (leaving aside in both cases the uninformative sequences in which the individual occupies the same state in each period). For general $\mathrm{T}$, there are $\left(2^{\top}-2\right)$ possible sequences which may be observed and this presents a formidable computational hurdle as a number of authors have

\footnotetext{
We exclude from the econometric analysis 136 women for whom employment status is missing in one or more of the 60 months. (For the descriptive analysis in Tables 2 and 3 we excluded only the missing months themselves.)
} 
noted. For example, Greene (1990) comments that the amount of computation "becomes excessive for T larger than five or six" (p.687) and his well-known LIMDEP package imposes a limit of $T=5$ on the user.

Estimation of the conditional logit model by maximum likelihood in a single step using a 11 our data with $T=60$ is clearly infeasible. In principle, one solution would be to use only a small sample of time-periods in estimation. However, it should be remembered that in only a small percent of months in our data is any unemployment of the husband recorded (see Table 2) and in addition some of the men concerned may be married to women who have the same employment status in each period - some two-thirds of the sample - who can in any case contribute nothing to the likelihood of the conditional logit mode1. For reasons of efficiency in estimation of the $\mathbf{b}$ therefore, we do need to estimate the model with all our data.

We overcome this apparent dilemma with a simple two-stage estimation technique which could be used by anyone wishing to estimate the Chamberlain model with non-trivial T. We divide our 60 months of SEP data into 12 smaller panels, each with $T=5$; the January months (one from each of the five years) form one pane1, the February months another, and so on. The 12 small panels are therefore overlapping. At the first stage we then obtain 12 sets of estimates of the $\mathbf{b}$ vector and their associated variance-covariance matrices by maximising the conditional likelihood for the Chamberlain model for each pane1. At the second stage we use minimum distance to impose equality restrictions on these $\mathbf{b}$ vectors and in addition obtain an estimate of the variance-covariance matrix of the new restricted parameter estimates. In this way we avoid discarding data. ${ }^{10}$

Let $p$ be the number of time-varying characteristics in $X_{i t}$, $B$ the stack of the 12 estimated $\mathbf{b}$, and $\mathbf{G}$ the estimates which we wish to obtain of the equality restricted $\mathbf{b}$; $\mathbf{B}$ has dimensions $12 \mathrm{px}$ l and $\mathbf{G}, \mathrm{px}$. More specifically,

10 The use of minimum distance at a second stage has been used to overcome problems of large microdata sets in another context by Browning and Meghir (1991). They est imate a demand system equation by equation in a first stage then use minimum distance to impose the cross-equation restrictions dictated by economic theory at a second stage. We thank Costas Meghir for suggesting the technique to us. In principle the technique is not fully efficient in our case since it may not use a 11 the data. For example, if a woman participates in a 11 the January months but never in any other month she would contribute to the conditional likelihood of a model with $T=60$ but will not contribute to the likelihood of any of the 12 panels we construct with $T=5$. To estimate the mode 1 we use LIMDEP at the first stage and GAUSS at the second. 
the second stage involves obtaining estimates of the restricted parameters $\mathbf{G}$ by estimating the relationship $\mathbf{B}=\mathbf{K} \mathbf{G}+\mathbf{e}$, by generalised least squares. The matrix $\mathbf{K}$ is a stack of 12 identity matrices, each with dimension pxp; $\mathbf{K}$ defines the equality restrictions on the $\mathbf{b}$. Thus we obtain $\mathbf{G}$ by:

$$
\mathbf{G}=\left(K^{\prime} \mathbf{V}^{-1} K\right)^{-1} K^{\prime} V^{-1} B
$$

The matrix $\mathbf{V}^{-1}$ is formed from the 12 estimated variance-covariance matrices from the first stage. Under the assumption of a static mode 1 there are no covariances between any two parameter estimates taken from a pair of b vectors obtained from different first stage $(T=5)$ panels. This allows $\mathbf{V}^{-1}$ to be formed as a block-diagonal matrix of dimension $12 p \times 12 p$ with the inverses of the first-stage estimated variance-covariance matrices down the leading diagonal (and all other elements zero). These estimates of $\mathbf{G}$ will give a minimised chi-squared value equal to $(\mathbf{G}-\mathbf{K B})^{\prime} \mathbf{V}^{-1}(\mathbf{G}-\mathbf{K B})$ with $11 \mathrm{p}$ degrees of freedom which may be used as a test of the equality restrictions on the first stage $\mathbf{b}$ estimates. An estimate of the variance-covariance matrix of the $\mathbf{G}$ is given by $\left(K^{\prime} \mathbf{V}^{-1} K\right)^{-1}$.

We noted in Section 2 that although we do use a balanced panel this is not in fact required by our econometric mode1. Consider, for example, those married couples who are observed for only three waves of the pane1, implying a maximum of $T=36$. We could split these data up and estimate 12 first-stage models with $T=3$ (there are obviously other ways of splitting) in addition to the 12 with $T=5$. Second stage estimation would then proceed with $B$ as a stack of 24 rather than 12 first-stage $b$ estimates and with dimensions of other matrices also adjusted (for example $V^{-1}$ would contain 24 inverses of stage one variance-covariance matrices). The point is that the length of any group of observations in the panel is no longer important at the second stage. A11 such problems can be dealt with at the first stage by obtaining separate estimates of $\mathbf{b}$ for each group that differs in $T$.

\section{Results}

Columns 4 and 5 of Table 4 give results obtained with the two-stage "conditional maximum likelihood - generalised least squares" (CML/GLS) technique described in the last section. The estimates in columns 1-3 are obtained with maximum likelihood (ML) under the assumption that the combined error $\left[a_{i}+u_{i t}\right]$ in equation (1) follows a multivariate logistic distribution, 
using the $\mathrm{N}$ times $\mathrm{T}$ observations as a giant cross-section (of 113,100 observations) and applying the familiar binary logit model to the data. In other words, we ignore the possible correlation of fixed effects with observables which is allowed for when we obtain the CML/GLS results. This provides a bench-mark against which we can assess the importance of unobserved fixed effects. " In contrast to the CML/GLS technique this model provides estimates of the $\mathbf{d}$, the parameters of the time invariant characteristics, as well as estimates of the $\mathbf{b}$. We include in $Z_{i}$ a variety of characteristics which are entered in the specification in column 3 . These are listed at the bottom of the table but the parameter estimates are not reported since they hold no interest for the purpose of this paper; our a im is merely to see how the estimated $\mathbf{b}$ in columns 1 and 2 change when we include a number of observable characteristics of the women. (These characteristics are entirely conventional for a reduced form participation equation.)

Time-varying characteristics include the variables relating to the husband's employment status and benefit receipt in which we are particularly interested. The assumption of strict exogeneity of these variables is a severe one. The use in this way of the employment status dummies implies that the wife takes the labour supply of the husband as given; we therefore make no recognition in our model of the large literature on other types of family decision making model. In the case of the benefit status variables we show in Table 4 the results of using a single dummy for UA, the category of benefit receipt associated with the lowest wives' participation rate and which implies a flat portion of the wife's budget constraint over a range of hours (assuming pooling of family income). It should be noted that this variable may not in principle be exogenous to the wife's participation decision; a wife working long hours could extinguish the UA entitlement. We return to this problem later. The other variables in $\mathbf{X}_{i t}$ are the regional (Lander) unemployment rate (time variation is annual) entered to pick up demand side effects, and a number of variables relating to the age and numbers of children (these may alter monthly). The time-invariant characteristics in column 3 are dummies indicating birth cohort, education and nationality. The SEP over-samples foreigners with the result that some $30 \%$ of our sample are not German natives.

11 The assumption of a multivariate logistic distribution for $\left[a_{i}+\right.$ $u_{i t}$ ] is inherently unattractive and is made only to have a bench-mark logit mode1. If $a_{i}$ is a random effect uncorrelated with included observables then a less restrictive assumption would be multivariate normal (see Maddala, 1987, for a summary of the options). 
We include a different set of educational variables for foreigners (the base for the education dummies is the lowest level of German education) together with nationality dummies.

The results in columns 1 and 2 reflect the earlier descriptives statistics in Tables 2 and 3 and provide a bench-mark against which to assess the effect of introducing further explanatory variables and of allowing for unobservables. Column 1 shows the lower on average participation rate of wives of the unemployed (the base for the dummies is an employed husband). Column 2 shows that in the presence of just those variables representing the employment status of the husband, the receipt by him of means-tested UA is associated with a significantly lower probability of the wife working, amounting to a maximum of about 20 percent points. ${ }^{12}$ As with the earlier descriptive analysis these effects have been found without controlling for other characteristics of the women concerned and in column 3 we introduce a range of those which we can observe but we continue to ignore the existence of the unobserved fixed-effect $a_{i}$. Only the coefficients of the additional time-varying $x_{i t}$ are reported. Not surprisingly, these have a considerable impact. One child aged $0-5$ reduces the participation probability by up to $25-$ 30 percent points. The regional (Lander) unemployment rate varies during the period from about $5 \%$ in Baden-Wurttemberg to over $15 \%$ in Bremen; its est imated coefficient implies that this variation is associated with a difference in the participation probability of up to 20 percent points.

Two features of the differences in the results between columns 2 and 3 may be noted. Firstly, the significantly negative coefficient on husband's UA does not disappear although its size is reduced by about one quarter. This suggests that only a part of the impact of this variable in column 2 represented the effects of characteristics for which we now control in column 3. In other words, the lower probability of the wife working when the husband receives UA is only to a minor degree explained by the unemployment rate of the region in which she lives, together with her birth cohort, human capita1, number and ages of children, and nationality. Secondly, when we control for such characteristics, husband's unemployment per se is associated with a slightly higher probability of participation, around 8 percent points at the

12

With the logit functional form the derivative of the probability of participation, $P$, with respect to an explanatory variable $X$ with coefficient $b$ is given by $d P / d X=P(1-P) b$. Division of each coefficient by 4 therefore shows the maximum marginal impact. 
maximum.

The results in columns 1-3 are obtained under the assumption that the unobserved $a_{i}$ is uncorrelated with included explanatory variables. Not only does this seem improbable a priori but the change in the coefficients of our principal variables of interest between columns 2 and 3 is informal evidence against the assumption. It seems unlikely that we have controlled in column 3 for a 11 possible influences on participation which might be correlated with the dummies for husband's employment status and UA receipt. The fixed-effects model estimated by the two-stage technique, the results from which are reported in columns 4 and 5 , allows for the $a_{i}$ to be correlated with included variables.

The null hypothesis of equality of first stage b coefficients cannot be rejected; the minimised chi-squared values reported in columns 4 and 5 are distributed with 33 and 99 degrees of freedom respectively. (This rejection of the null is not surprising given the overlapping scheme we used to construct the short stage one panels.) The Hausman statistics for the significance of fixed effects given at the bottom of columns 4 and 5 are also chi-squared statistics, with 3 and 9 degrees of freedom respectively; both show the importance of allowing for fixed effects (the size of the statistic in column 5 is driven by the big change in the estimated impact of the age of the youngest child.) The following conclusions can be drawn from these results concerning the impact of allowing for the fixed-effects.

1. There appears to be no significant association of husband's unemployment per se with the wife's participation status. This is shown most simply by the results in column 4 where we include no additional observable characteristics to the husband's employment status variables; allowing for unobservables results in the disappearance of the significant negative coefficient on husband's unemployment in column 1. Likewise the significant positive coefficient in column 3 is not present in column 5 .

2. Women with a husband out of the labour force do have a lower probability of participation, by up to 10-12 percent points. This association in the data in the descriptive analysis survives after allowance is made for both observables and unobservables.

3. There is no evidence that the estimated effects of children are overstated 
in the cross-section approach: the allowance for fixed-effects increases (in absolute size) all but one of the coefficients concerned, very markedly in the case of the variable relating to the age of the youngest child (something worthy of more investigation). This contrasts with the findings of Jakubson (1988) for the US (it should be noted that Jakubson uses the Tobit specification rather than a binary model).

4. The regional unemployment rate maintains its negative impact, the coefficient increasing in absolute size. This would appear to confirm the presence of important demand side effects on the participation probability. (This variable displays much less temporal than regional variation during the period in question, hence the large drop in the precision of the estimated coefficient).

4. The estimated coefficient of the dummy indicating a husband on UA is not driven down to zero. There is in fact a slight increase from column 3 and the value is only 15\% lower than in column 2 where there are no controls at a11; the null hypothesis that the true parameter is zero is rejected at conventional significance levels. (In a specification identical to that in column 2 the coefficient on UA is almost identical to that in column 5.) The apparent implication is that the lower participation rate of wives of men receiving means-tested unemployment benefit is only to a small degree explained by observable and unobservable characteristics of the wife which are correlated with her husband's benefit status. It should however be noted that with the size of sample concerned, the relevant parameter in column 5 cannot be considered as being determined with very great precision.

We noted earlier that in principle the UA dummy is endogenous. If the wife works long hours she can extinguish her husband's UA entitlement; the negative association between the wife's participation probability and the husband's UA status could reflect causality running in this direction, rather than from UA to participation as we have hypothesised. This issue requires our attention in future work. Here we merely report the results of using a dummy variable indicating that the husband receives UI, which is not subject to a means-test, in place of the dummy indicating means-tested UA receipt. This variable does not suffer from the same problem of endogeneity and it might reasonably be thought that we could expect a positive coefficient 
relative to a base of means-tested UA or no benefit since the receipt of UI by the husband is a clear indication that there can be no potential UA disincentive operating (receipt of UI rules out eligibility for UA). After controlling for both observables and unobservables (using the specification of these other influences in column 5 ) we obtain an estimated coefficient on the husband's UI dummy of -0.162 (standard error 0.180 ). This appears to be inconsistent with the UA disincentive story. 
Table 4

Logit Parameter Estimates of Probability of Wife Working

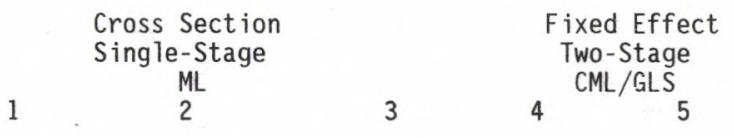

Constant

Time-Varying

Characteristics $\left(\boldsymbol{X}_{i \mathrm{t}}\right)$

Husband:

Unemp loyed

Out of labour force

employment status missing

getting Unemp loyment

Assistance (UA)

Lander Unemployment rate (\%)

Children:

Number aged 0-5

Number aged 6-15

Number aged $16+$

Age of Youngest (months/12)

Fixed Characteristics $\left(Z_{i}\right)$

-Log-Likelihood (single stage ML)

78,199

0.077

$(0.1)$

(5.8)

$-0.084$

(3.4)

$-0.276$

(2.3)

$-0.083$

(3.4)

$-0.276$

(2.3)

$-0.870$

(12.1)

0.246

(7.7)

$-0.098$

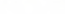

$-0.086$

(32.0)

$-1.114$

(69.1)

$-0.499$

(45.7)

$-0.116$

(11.6)

0.009

(7.5)

NO

YES

$78,122 \quad 71,601$

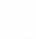

$\begin{array}{rr}0.335 & -0.014 \\ (7.8) & (0.1) \\ 0.104 & -0.434 \\ (3.9) & (4.5) \\ -0.190 & -0.135 \\ (1.6) & (0.5) \\ -0.644 & \\ (8.3) & \end{array}$

$-0.001$

0.1 )

$(0.1)$

(4.5)

$-0.135$

$-0.517)$

-0.17 .7
$(0.6)$

$-0.737$

(3. 으)

$-0.1 \frac{135}{5}$

(4. 3)

$-1.148$

(20.4)

$-0.437$

(8.2)

$-0.290$

(4.5)

0.102

$(14.0)$ 의

$-\frac{2}{2}$

(2)

Chi-squared test of equality of

first stage estimates (CML/GLS)

9.6

51.8

Hausman test of fixed effects

19.9

255.8

Note: 1) log-likelihood with constant only in ML model $=-78,224$.

2) t-statistics in brackets

3) Fixed Characteristics $\left(Z_{i}\right)$ included in the specification in column 3: five dummies for year of wife's birth (1935-39, 1940-44, 1945-49, 1950-54,1955+), twelve dummies for wife's education (education record missing, German intermediate, German Upper secondary school, German professional college, German university, foreign compulsory without qualification, foreign compulsory with qualification, foreign further Schooling, foreign Professional School, foreign university, foreign vocational training, foreign no schooling), four dummies for wife's nationality (Turkish, Yugoslav, Greek, other nonGerman). 


\section{Conclusions}

In this paper we have considered the effect of unemployment experienced by a married man on his wife's labour supply. An econometric investigation was undertaken to shed more light on suggestive results from descriptive analysis. We have assumed the husband's employment status to be exogenous and have paid particular attention to the type of unemployment benefit he receives. Using a two-stage technique because of the computational burden posed by a long pane 1 we estimated a static binary model of participation with German household data allowing for unobservable fixed effects correlated with observables.

The results of the model suggest that there could be a disincentive impact on family labour supply from the means-testing of UA. Such a disincentive would be predicted by a static theoretical model of labourleisure choice. However, in reality the disincentive from the UA system is temporary, lasting only as long as the husband continues to be unemployed. A dynamic theoretical model can explain why women work despite the UA system posing a large disincentive (Dustmann and Micklewright, 1991).

Women in Germany married to unemployed men may have a participation rate which is in part influenced by the institutional details of the German unemployment benefit system (and their husband's employment status), although our results have also indicated the importance of demand side factors. Any firmer conclusions concerning this important issue - which concerns the unemployment benefit systems in other countries too - would require more detailed use of data and estimation of alternative econometric models. 


\section{$\underline{\text { References }}$}

Atkinson, A B and Micklewright, forthcoming, "Unemployment Compensation and Labour Market Transitions: A Critical Review", Journal of Economic Literature.

Brinkmann, C, 1988, "The Income of the Unemployed in the Federal Republic of Germany: Data Sources, Concepts and Resu1ts", Institute of Employment Research of the Federal Republic of Germany, Nuremberg.

Browning, M, and Meghir, C, 1991, "The Effects of Male and Female Labour Supply on Commodity Demands", Econometrica, vol 59, no 4, pp925-952.

Chamberlain, G, 1980 "Analys is of Covariance with Qualitative Data", Review of Economic Studies, vol 47, pp.225-38.

Davies, R, Francis, B, Barry, J, and Penn, R, 1989, "The Relationship between a Husband's Unemployment and his Wife's Participation in the Labour Force", paper presented to the Social Statistics Section of the Royal Statistical Society, 16th May 1989.

Dilnot, A and Ke11, M, 1987, "Male Unemployment and Women's Work", Fiscal Studies, vol 8, no $3,1-16$.

Dustmann, C, and Micklewright, J, 1991, "Means-Tested Unemployment Benef it and Family Labour Supply: An Intertemporal Analysis", mimeo, European University Institute.

Garcia, J, 1989, "Incentive and Welfare Effects of Reforming the British Benefit System: a Simulation Study for the Wives of the Unemployed" in S Nicke 11, W Narendranathan, J Stern and J Garcia, The Nature of Unemployment in Britain, Oxford University Press, 0xford.

Garcia J, 1991, "A Participation Mode1 with Non-Convex Budget Sets: the Case of the Wives of the Unemployed in Great Britain", Applied Economics, vol 23, pp.1401-1416.

Greene, W H, 1990, Econometric Analysis, Macmillan, New York.

Jakubson, G, "The Sensitivity of Labour-Supply Parameter Estimates to Unobserved Individual Effects: Fixed- and Random-Effects Estimates in a Nonlinear Model using Panel Data", Journal of Labor Economics, vol 6, no 3, pp.302-329.

Jensen, P, and Smith, N, "Unemployment and Marital Dissolution", Journal of Population Economics, vol 3, pp.215-229.

Ke11, M and Wright, J, 1990, "Benefits and the Labour Supply of Women Married to Unemp loyed Men", Economic Journa 1, Conference Papers Supplement, pp119-126.

Lundberg, S, 1985, "The Added Worker Effect", Journal of Labor Economics, vol 3 , pp.11-37. 
Maddala, G S, 1987, "Limited Dependent Variable Models Using Panel Data", Journal of Human Resources, vol 22, no 3, pp.307-338.

Maloney, T, 1991, "Unobserved Variables and the Elusive Added Worker Effect", Economica, vol 58, no 230, pp.173-188.

Narendranathan, W, and Elias, P, 1990, "Influences of Past History on the Incidence of Youth Unemployment: Empirical Findings for the UK", University of Warwick Economic Research Paper 369.

Smeeding, T, 0'Higgins M, and Ra inwater L (eds), 1990, Poverty, Inequality and Income Distribution in Comparative Perspective: the Luxembourg Income Study, Harvester Wheatsheaf. 


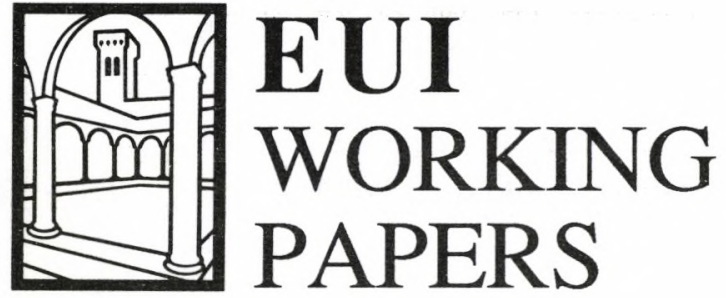

EUI Working Papers are published and distributed by the European University Institute, Florence

Copies can be obtained free of charge - depending on the availability of stocks - from:

The Publications Officer

European University Institute

Badia Fiesolana

I-50016 San Domenico di Fiesole (FI)

Italy

Please use order form overleaf 


\section{Publications of the European University Institute}

To

The Publications Officer

European University Institute

Badia Fiesolana

I-50016 San Domenico di Fiesole (FI)

Italy

From Name

Address . . . . . . . . . . . .

$\checkmark$ Please send me a complete list of EUI Working Papers

$\square$ Please send me a complete list of EUI book publications

$\square$ Please send me the EUI brochure Academic Year 1990/91

Please send me the following EUI Working Paper(s):

No, Author

Title:

No, Author

Title:

No, Author

Title:

No, Author

Title:

Date

Signature 


\section{Working Papers of the Department of Economics Published since 1989}

$89 / 370$

B. BENSAID/ R.J. GARY-BOBO/

S. FEDERBUSCH

The Strategic Aspects of Profit Sharing in the Industry

\section{$89 / 374$}

Francisco S. TORRES

Small Countries and Exogenous Policy Shocks

\section{$89 / 375$}

Renzo DAVIDDI

Rouble Convertibility: A Realistic Target

89/377

Elettra AGLIARDI

On the Robustness of Contestability Theory

$89 / 378$

Stephen MARTIN

The Welfare Consequences of Transaction Costs in Financial Markets

\section{$89 / 381$}

Susan SENIOR NELLO

Recent Developments in Relations Between the $\mathrm{EC}$ and Eastem Europe

\section{$89 / 382$}

Jean GABSZEWICZ/ Paolo GARELLA/

Charles NOLLET

Spatial Price Competition With Uninformed Buyers

\section{$89 / 383$}

Benedetto GUI

Beneficiary and Dominant Roles in

Organizations: The Case of Nonprofits

\section{$89 / 384$}

Agustín MARAVALL/ Daniel PEÑA Missing Observations, Additive Outliers and Inverse Autocorrelation Function

\section{$89 / 385$}

Stephen MARTIN

Product Differentiation and Market Performance in Oligopoly

\section{$89 / 386$}

Dalia MARIN

Is the Export-Led Growth Hypothesis Valid for Industrialized Countries?

\section{$89 / 387$}

Stephen MARTIN

Modeling Oligopolistic Interaction

\section{$89 / 388$}

Jean-Claude CHOURAQUI

The Conduct of Monetary Policy: What have we Learned From Recent Experience

\section{$89 / 390$}

Corrado BENASSI

Imperfect Information and Financial Markets: A General Equilibrium Model

\section{$89 / 394$}

Serge-Christophe KOLM

Adequacy, Equity and Fundamental Dominance: Unanimous and Comparable Allocations in Rational Social Choice, with Applications to Marriage and Wages

\section{9/395}

Daniel HEYMANN/ Axel LEIJONHUFVUD On the Use of Currency Reform in Inflation Stabilization

\section{$89 / 400$}

Robert J. GARY-BOBO

On the Existence of Equilibrium Configurations in a Class of Asymmetric Market Entry Games *

$89 / 402$

Stephen MARTIN

Direct Foreign Investment in The United States

\section{9/413}

Francisco S. TORRES

Portugal, the EMS and 1992: Stabilization and Liberalization

\section{$89 / 416$}

Joerg MAYER

Reserve Switches and Exchange-Rate Variability: The Presumed Inherent Instability of the Multiple Reserve-Currency System

\section{9/417}

José P. ESPERANÇA/ Neil KAY Foreign Direct Investment and Competition in the Advertising Sector: The Italian Case 
$89 / 418$

Luigi BRIGHI/ Mario FORNI

Aggregation Across Agents in Demand Systems

$89 / 420$

Corrado BENASSI

A Competitive Model of Credit Intermediation

$89 / 422$

Marcus MILLER/ Mark SALMON

When does Coordination pay?

$89 / 423$

Marcus MILLER/ Mark SALMON/

Alan SUTHERLAND

Time Consistency, Discounting and the Returns to Cooperation

\section{$89 / 424$}

Frank CRITCHLEY/ Paul MARRIOTT/

Mark SALMON

On the Differential Geometry of the Wald Test with Nonlinear Restrictions

$89 / 425$

Peter J. HAMMOND

On the Impossibility of Perfect Capital Markets

$89 / 426$

Peter J. HAMMOND

Perfected Option Markets in Economies with

Adverse Selection

$89 / 427$

Peter J. HAMMOND

Irreducibility, Resource Relatedness, and Survival with Individual Non-Convexities

$$
\text { *** }
$$

ECO No. 90/1“

Tamer BASAR and Mark SALMON

Credibility and the Value of Information

Transmission in a Model of Monetary Policy and Inflation

ECO No. 90/2

Horst UNGERER

The EMS - The First Ten Years

Policies - Developments - Evolution

ECO No. 90/3

Peter J. HAMMOND

Interpersonal Comparisons of Utility: Why and how they are and should be made

** Please note: As from January 1990, the EUI Working Papers Series is divided into six sub-series, each series will be numbered individually (e.g. EUI Working Paper LAW No. 90/1).
ECO No. $90 / 4$

Peter J. HAMMOND

A Revelation Principle for (Boundedly) Bayesian Rationalizable Strategies

ECO No. 90/5

Peter J. HAMMOND

Independence of Irrelevant Interpersonal

Comparisons

ECO No. 90/6

Hal R. VARIAN

A Solution to the Problem of Externalities and Public Goods when Agents are Well-Informed

ECO No. 90/7

Hal R. VARIAN

Sequential Provision of Public Goods

ECO No. $90 / 8$

T. BRIANZA, L. PHLIPS and J.F. RICHARD

Futures Markets, Speculation and Monopoly

Pricing

ECO No. $90 / 9$

Anthony B. ATKINSON/ John

MICKLEWRIGHT

Unemployment Compensation and Labour

Market Transition: A Critical Review

ECO No. $90 / 10$

Peter J. HAMMOND

The Role of Information in Economics

ECO No. 90/11

Nicos M. CHRISTODOULAKIS

Debt Dynamics in a Small Open Economy

ECO No. $90 / 12$

Stephen C. SMITH

On the Economic Rationale for Codetermination Law

ECO No. $90 / 13$

Elettra AGLIARDI

Learning by Doing and Market Structures

ECO No. 90/14

Peter J. HAMMOND

Intertemporal Objectives

ECO No. 90/15

Andrew EVANS/Stephen MARTIN

Socially Acceptable Distortion of Competition: EC Policy on State Aid 
ECO No. 90/16

Stephen MARTIN

Fringe Size and Cartel Stability

ECO No. 90/17

John MICKLEWRIGHT

Why Do Less Than a Quarter of the

Unemployed in Britain Receive Unemployment

Insurance?

ECO No. $90 / 18$

Mrudula A. PATEL

Optimal Life Cycle Saving

With Borrowing Constraints:

A Graphical Solution

ECO No. 90/19

Peter J. HAMMOND

Money Metric Measures of Individual and Social

Welfare Allowing for Environmental

Externalities

ECO No. 90/20

Louis PHLIPS/

Ronald M. HARSTAD

Oligopolistic Manipulation of Spot Markets and the Timing of Futures Market Speculation

ECO No. 90/21

Christian DUSTMANN

Earnings Adjustment of Temporary Migrants

ECO No. 90/22

John MICKLEWRIGHT

The Reform of Unemployment Compensation:

Choices for East and West

ECO No. $90 / 23$

Joerg MAYER

U. S. Dollar and Deutschmark as Reserve Assets

ECO No. 90/24

Sheila MARNIE

Labour Market Reform in the USSR:

Fact or Fiction?

ECO No. $90 / 25$

Peter JENSEN/

Niels WESTERGÅRD-NIELSEN

Temporary Layoffs and the Duration of

Unemployment: An Empirical Analysis

ECO No. $90 / 26$

Stephan L. KALB

Market-Led Approaches to European Monetary

Union in the Light of a Legal Restrictions

Theory of Money
ECO No. 90/27

Robert J. WALDMANN

Implausible Results or Implausible Data?

Anomalies in the Construction of Value Added

Data and Implications for Estimates of Price-

Cost Markups

ECO No. $90 / 28$

Stephen MARTIN

Periodic Model Changes in Oligopoly

ECO No. $90 / 29$

Nicos CHRISTODOULAKIS/

Martin WEALE

Imperfect Competition in an Open Economy

$$
\text { *** }
$$

ECO No. 91/30

Steve ALPERN/Dennis J. SNOWER

Unemployment Through 'Learning From

Experience'

ECO No. 91/31

David M. PRESCOTT/Thanasis STENGOS

Testing for Forecastible Nonlinear Dependence in Weekly Gold Rates of Return

ECO No. $91 / 32$

Peter J. HAMMOND

Harsanyi's Utilitarian Theorem:

A Simpler Proof and Some Ethical

Connotations

ECO No. $91 / 33$

Anthony B. ATKINSON/

John MICKLEWRIGHT

Economic Transformation in Eastern Europe and the Distribution of Income

ECO No. 91/34

Svend ALBAEK

On Nash and Stackelberg Equilibria when Costs are Private Information

ECO No. 91/35

Stephen MARTIN

Private and Social Incentives

to Form R \& D Joint Ventures

ECO No. 91/36

Louis PHLIPS

Manipulation of Crude Oil Futures

ECO No. 91/37

Xavier CALSAMIGLIA/Alan KIRMAN

A Unique Informationally Efficient and

Decentralized Mechanism With Fair Outcomes 
ECO No. 91/38

George S. ALOGOSKOUFIS/

Thanasis STENGOS

Testing for Nonlinear Dynamics in Historical

Unemployment Series

ECO No. 91/39

Peter J. HAMMOND

The Moral Status of Profits and Other Rewards:

A Perspective From Modern Welfare Economics

ECO No. 91/40

Vincent BROUSSEAU/Alan KIRMAN

The Dynamics of Learning

in Mis-Specified Models

ECO No. 91/41

Robert James WALDMANN

Assessing the Relative Sizes of Industry- and

Nation Specific Shocks to Output

ECO No. 91/42

Thorsten HENS/Alan KIRMAN/Louis PHLIPS

Exchange Rates and Oligopoly

ECO No. 91/43

Peter J. HAMMOND

Consequentialist Decision Theory and

Utilitarian Ethics

ECO No. 91/44

Stephen MARTIN

Endogenous Firm Efficiency in a Cournot

Principal-Agent Model

ECO No. 91/45

Svend ALBAEK

Upstream or Downstream Information Sharing?

ECO No. 91/46

Thomas H. McCURDY/

Thanasis STENGOS

A Comparison of Risk-Premium Forecasts

Implied by Parametric Versus Nonparametric

Conditional Mean Estimators

ECO No. 91/47

Christian DUSTMANN

Temporary Migration and the Investment into

Human Capital

ECO No. 91/48

Jean-Daniel GUIGOU

Should Bankruptcy Proceedings be Initiated by a

Mixed Creditor/Shareholder?

ECO No. 91/49

Nick VRIEND

Market-Making and Decentralized Trade
ECO No. 91/50

Jeffrey L. COLES/Peter J. HAMMOND

Walrasian Equilibrium without Survival:

Existence, Efficiency, and Remedial Policy

ECO No. 91/51

Frank CRITCHLEY/Paul MARRIOTT/

Mark SALMON

Preferred Point Geometry and Statistical

Manifolds

ECO No. 91/52

Costanza TORRICELLI

The Influence of Futures on Spot Price

Volatility in a Model for a Storable Commodity

ECO No. 91/53

Frank CRITCHLEY/Paul MARRIOTT/

Mark SALMON

Preferred Point Geometry and the Local

Differential Geometry of the Kullback-Leibler

Divergence

ECO No. 91/54

Peter MØLLGAARD/

Louis PHLIPS

Oil Futures and Strategic

Stocks at Sea

ECO No. 91/55

Christian DUSTMANN/

John MICKLEWRIGHT

Benefits, Incentives and Uncertainty

ECO No. 91/56

John MICKLEWRIGHT/

Gianna GIANNELLI

Why do Women Married to Unemployed Men have Low Participation Rates?

ECO No. 91/57

John MICKLEWRIGHT

Income Support for the Unemployed

in Hungary 


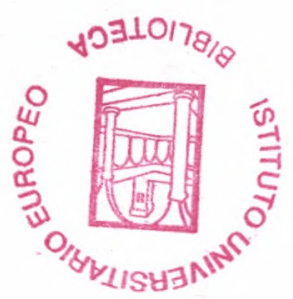


